\title{
Initial Exploration of Aesthetic Value of Calligraphic Art
}

\author{
Lijuan Pu \\ Hebei Academy of Fine Arts, Xinle Hebei, 050700, China
}

Keywords: Calligraphic Art, Aesthetics, Value

\begin{abstract}
Writing is an important written tool for people to convey their emotions and exchange ideas, of high practical value. Besides, writing is also of high aesthetic value, especially in Chinese characters. The Chinese characters have an integral structure, and various shapes. The Chinese characters presented by means of artistic expression are called calligraphic art with Chinese traditional culture features. The calligraphic art shows its aesthetics from many aspects. In this article, the reason why calligraphic art is of aesthetic value will be analyzed, and the aesthetic value of calligraphic art will be focused on, with an aim to drawing more attention to Chinese calligraphic art, and letting more people appreciate its unique aesthetic value.
\end{abstract}

\section{Introduction}

Calligraphy is an art about strokes. Calligraphers make strokes into wonderful artistic work full of vitality, quality feeling, lingering charm and substance based on their accomplishment about the length, thickness and layout of stokes. The level of calligraphy is highly dependent on the knowledge, accomplishment and disposition of calligraphers. Since its emergence, the calligraphic art has been playing an important role in public administration, historical record compilation, literary creation, etc. Meanwhile, the artistic quality of Chinese characters, together with the polishment and creation by calligraphers, makes calligraphic art be of high aesthetic value, so that the ancient literary men and people of all ranks had a passion for, appreciated and collected calligraphy works. With the rapid development of China's economy, people's spiritual and cultural life is also constantly improved, and more and more people seek after various art works, including porcelain, traditional Chinese painting, oil painting, sculpture, pottery, etc. However, calligraphy works have been being ignored, which is the essence of Chinese traditional culture, and called the mother of traditional Chinese painting. As a best representative art form with Chinese traditional culture features, calligraphy is unparalleled in respect of the popularity. One of the important reasons is the unique aesthetic value of calligraphic art.

\section{Analysis of Reasons of Aesthetic Value of Calligraphic Art}

Inspiration is very important in calligraphy creation. An inspirational person is always a person with special personalities and individual styles. High buildings rise from the ground. The writing of regular script is the basis for other writing styles. In the viewpoint of the writer, a solid foundation should be laid first in the process of calligraphy learning, namely the regular script should be mastered first, which is a long process. Otherwise, if the foundation is not solid enough, it is difficult to master other writing styles. Generally, the process of laying foundation will take over ten years by writing millions of characters. A minute on the state takes ten-year practice. Some calligraphy enthusiasts usually imitate the works of masters to run prizes in calligraphy competition, with a hope to acquire fame and raise their prestige, and they will become self-important. A real master of calligraphy does not only have great accomplishments in calligraphy, but also respects other people, and is honest and modest. This is the personality of a real master of calligraphy.

Imposing manner is important in calligraphy. Any art form cannot stand independent from the pursuit of the supreme aesthetic ideal, which is usually attained in an imposing manner. It is the same for a performing artist, whose all behaviors are to present the romantic charm. Coherence and proficiency is another factor should be emphasized in calligraphy. Practice makes perfect, and perfect makes wonderful. This means that a performer should smoothly make every movement to the music. 
A calligrapher should know the content to be written well, as an actor should know the spoken parts and libretto well. If a calligrapher does not know the content well, he is bound to be interrupted again and again, but not write at one stretch. In this way, it is impossible to make smooth and coherent works. Besides, high-quality Chinese art paper should be selected. A great master of calligraphy will prepare ink according to the quality of the Chinese art paper. If the quality of the Chinese art paper is low, little water or no should be added into the ink. Contrarily, if the quality of the Chinese art paper is high, a proper quantity of water can be added. The last factor to be emphasized in calligraphy is writing brush. Although there is an old saying of a master of calligraphy will not be affected by bad writing brush, it is better to choose a good writing brush. Actually, most calligraphers will be affected by bad writing brush, which will affect their level of calligraphy accordingly. Writing brush is a unique writing tool invented by Chinese. A good writing brush will make for the creation, so as to show the aesthetic value of calligraphic art better.

\section{Description of Aesthetic Value of Calligraphic Art}

\section{Aesthetics of Calligraphic Art in Respect of Strokes}

Chinese calligraphic art exists based on the construction of strokes. Strokes are the most important part of calligraphic art. The high level of a calligraphy work means that the quality of the strokes is high. Which type of strokes are the best? In the viewpoint of the writer, the powerful and vigorous ones are the best. The China's ancients have coined many words to describe calligraphic strokes, such as succinct, efficient, internally powerful, long spears and halberds, penetrating, etc. All these words are words to describe calligraphic strokes from the perspective of force. The reason why powerful and vigorous strokes are the best is that only characters written with powerful and vigorous strokes are of vitality and vigor. Originally, the word of penetrating was coined to describe that calligraphy works were written with a force strong enough to penetrate wood. This marks the basic criteria for judging the aesthetic value of calligraphic art established by the China's ancients. Writing powerful and vigorous strokes is the basic requirement for calligraphy creation. Only by powerful and vigorous strokes, can a calligraphic work not look fickle or shallow but look steady and profound, showing both force and weight. Therefore, solid strokes can be called the life of calligraphy. The word of penetrating exactly refers to the "force" in calligraphic art, and a direct feel of us when appreciating calligraphy works. It is a kind of feeling, so it falls into the scope of the psychology. The rhythm beauty of strokes of calligraphy was called water stains on the wall, of which the typical representative is the works of Yan Zhenqin. The real meaning of writing in dotted lines is that rainwater gradually penetrates into the wall, and the running muddy water flows downwards along the uneven wall to leave flexuous stains. The dotted line of water in nature was the exact source of inspiration in calligraphy creation, which has played a dignified and vigorous melody of calligraphy.

\section{Aesthetics of Calligraphic Art in Respect of Ink Color}

The color composition in the Chinese calligraphic art is very simple, namely white paper plus black characters. Simple as it is, such a white-black composition distinguishes the wonderful calligraphic art, making it comparable with the art of painting. The extraordinary value of ink color is the right factor making calligraphic art so charming and unique. With a brush with ink of different quantity and concentrations, you can draw thick, thin, squared or round lines. If the brush is not completely saturated, the lines drawn will appear like explosion and looks penetrating. Otherwise, if the brush is completely saturated, the tip will be humid enough to mould various shapes of characters. Besides, layering can be made by drawing with inks of different concentrations, showing a special artistic effect. Before the Song Dynasty, the Chinese calligraphers mainly used thick ink in calligraphy creation. These masterpieces created with thick ink were vividly compared to the black eyes of children by Su Dongpo. Generally, children's eyes are lustrous black, glittering and bright. Besides, controlling the moistening and dryness of ink is another way to distinguish calligraphic works. In running script, both moist and dry strokes are required. The former is to make the work beautiful, and the latter to distinguish. Moist strokes do not mean overly saturating the brush, because 
an overly saturated brush is not effective to control the shape of strokes, and characters written with an overly saturated brush will look plumb, swollen and forceless. Of course, dryness does not mean dullness either, because dullness means lifelessness.

\section{Aesthetics of Calligraphic Art in Respect of Shape}

There are many stories about calligraphy creation in the calligraphy history of China. For example, it is said that Wang Xizhi, a master of calligraphy, got an inspiration from the shape and posture of goose after looking geese swimming in water and going ashore, and he applied this aspiration into his works. Another example is Zhang Xu, a famous calligrapher known for running script in the Tang Dynasty. He got an inspiration from the sword dance created by Lady Gongsun, the most famous dancer at that time. Thus, it can be seen that the aesthetic value of calligraphic art cannot stand independent from the shape and form. If the exquisite western paintings depict human body to praise the beautify body in nature, then the structure of Chinese characters combining dot and line in calligraphy is made to show a kind of abstract beauty of shape, which can be showed in various gestures. Since the invention, the hieroglyph of China has been evolving, so as to cut out the superfluous. Thus, the shape of the hieroglyph and the objects stood for the hieroglyph have little in common, and the hieroglyph became with dim beauty, giving a large room to people for considering, imagining and feeling. Deng Shiru pointed out that the gap of a character can either be broad enough for a horse to go through, or be closed up tight. Gaplessness means the lack of room, while uncloseness means the lack of solidness sense. The structure of a character is like that of a building, which will look really beautiful only by subtly combining the high and low rooms. Take the example of the character of "Shi (实)" in the work titled by the Leek Flower Ode created by Yang Ningshi in the Five Dynasties and Ten Kingdoms Period. A blank had been intentionally left below the upper component ( $\overrightarrow{ }$ ), forming an ideorealm of physical isolation but spiritual coherence. It can be said that most great masters of calligraphy highlight the shape beautify in works. Thus, the beauty of room and change is very important in the artistic structure of calligraphy works.

\section{Aesthetics of Calligraphic Art in Respect of Artistic Conception}

Comparing with contemporary abstract painting works, the artistic conception of calligraphy works looks simpler. The artistic conception of calligraphy works is showed on the basis of breathing and actions of human, reflecting the real life. In order to realize such artistic conception, various measures can be resorted to, or nothing can be done, which is the indescribable hollowness reflected by the artistic conception of calligraphy works. As to ideological practice, the hollowness seems very important, because with which human can make use of all meaningless and unrelated activities in daily life to develop their ideas. The most important thing in calligraphy creation is to actively create a beautiful artistic conception. As to appreciation of art works, the creation of artistic conception also is an important criterion. Because of this, the Chinese calligraphers always attach great importance to the creation of artistic conception. The artistic conception of a calligraphy work mainly refers to the thought, feeling and style of the work, and covers mainly things and contents, which can completely show the level and mood of the creators. A calligraphy work of a beautiful artistic conception always will be favored by people for a long time. If a calligraphy work looks exquisite in terms of form, but lacks a good artistic conception, it is just gold outside and empty inward, and cannot be called a real calligraphy work.

\section{Conclusion}

As a whole, calligraphic art is closely linked with the cultural path, looking solemn and respectful, or natural, or vehement. The appreciation and promotion of calligraphic art is the main way for Chinese people to boost the self-confidence in reliance upon traditional culture. Calligraphic art is featured by the breath of life and high spirit, has the styles of simplicity, honesty, power, vigor, relaxation, etc., or has the texture of profoundness and sophistication, and can absorb different elements throughout its development. With vivid and vigorous strokes and misting with space, the calligraphic art can lead the appreciators into an ocean of the Chinese traditional culture, to seek the 
lost cultural genes, have an interesting dialogue with the ancient languages, and make the contemporary time intersect with the ancient civilization. Thus, as an important part of the Chinese traditional culture, the calligraphic art needs deeper research for a better and further development.

\section{References}

[1] QIU Ling. Opinions on the Beauty of Chinese Calligraphic Art. Journal of Tongling University, 2003 (1).

[2] ZHENG Guoxian, ZHOU Guangsheng, JIANG Shuxue. Correlation between Aesthetic Value of Characters and Calligraphic Art. Journal of Shijiazhuang University of Economics, 2003 (2).

[3] ZHANG Xiangqi. Initial Exploration of Artistic Value of Chinese Calligraphy. Urban Construction Theory Research, 2012 (22).

[4] LI Rongcheng. Brief Analysis of Artistic Characteristics of Calligraphy Works of Li Guangdi. Journal of Yangtze University, 2012 (9).

[5] LU Jun. Research and Analysis of Aesthetic Value of Calligraphy. Culture and Art $\cdot$ Art and Literary Circle, 2014 (6). 